\section{Moving Velcade into lupus}

\section{By Tim Fulmer, Senior Writer}

Memory B cells and short- and long-lived plasma cells secrete autoantibodies that are thought to be at the root of lupus. ${ }^{1,2}$ Short-lived plasma cells can be targeted indirectly by blocking $B$ cell activation, but that approach has been disappointing, as illustrated by the recent failure of B cell-depleting antibody Rituxan rituximab in a Phase II/ III lupus trial. Long-lived plasma cells have remained therapeutically intractable. $^{3}$

A paper in Nature Medicine indicates that Velcade bortezomib might offer a therapeutic option in lupus, as the small molecule proteasome inhibitor depletes both short- and long-lived plasma cells. Academic and company researchers are concerned about potential side effects, however, because a proteasome inhibitor may not be sufficiently selective to target only autoantibody-producing plasma cells.

Lupus is a chronic autoimmune disease characterized by excessive production of autoantibodies that can cause severe damage to the skin, kidneys, nervous system, blood and other organs. Strategies to treat the disease have aimed to suppress or at least significantly reduce autoantibody levels by targeting subpopulations of the B cell family (see Table 1, "Lupus pipeline"). For example, the monoclonal antibody Rituxan targets the CD20 receptor, which is expressed on mature and memory B cells, but not on plasma cells.

Because plasma cells have few if any cell surface markers in common with mature and memory B cells, targeting them with therapies like Rituxan is unlikely. Moreover, it is still unclear where in the plasma cell developmental pathway intervention would best prevent autoantibody production. ${ }^{4}$ Consequently, there are as yet no therapies in the clinic that directly target either short- or long-lived plasma cells.

The Nature Medicine article builds on previous work by two different labs. Rudolf Manz and colleagues have shown that autoantibody-secreting plasma cells contribute to autoimmune disease in a mouse model of lupus. ${ }^{5}$ Reinhard Voll and colleagues have reported that high rates of antibody production sensitized multiple myeloma cells to bortezomib. ${ }^{6}$

In the latest paper, Voll and Manz jointly investigated whether bortezomib's efficacy against malignant plasma cells translated into efficacy against autoantibody-producing plasma cells in lupus. ${ }^{\text {? }}$

In initial experiments in a murine model of lupus nephritis, bortezomib targeted and depleted plasma cells. The researchers found that this depletion correlated with improvements on key disease endpoints. In the mice, twice-weekly administration of bortezomib significantly lowered autoantibody levels and prolonged survival compared with what was seen in mice that received saline buffer control $(p<0.001$ for both).

In a second murine model of aggressive lupus with both kidney and skin involvement, bortezomib again significantly lowered autoantibody levels and increased survival compared with what was seen in controls ( $p=0.04$ and $p=0.03$, respectively).

Manz told SciBX that the continuous production of autoantibodies in systemic lupus erythematosus is due to two mechanisms. The first of these is chronic B cell activation that leads to the formation of short-lived plasma cells, whereas the second is survival of long-lived plasma cells, he said.

Thus, even in patients who respond well to conventional lupus therapies, said Manz, "persistent but low-level autoantibody production by long-lived plasma cells is likely contributing to increased risk for relapse." In patients who respond poorly to conventional therapy, he said, "long-lived plasma cells might be the major source of autoantibodies."

Manz, a researcher in the Department of Humoral Immunology at the German Arthritis Research Center, therefore expects that bortezomib could be useful in treating lupus patients who respond poorly or not at all to immunosuppressants or B cell-depletion therapy.

\section{Not so fast}

Velcade is marketed by Millennium Pharmaceuticals Inc., a subsidiary of Takeda Pharmaceutical Co., and Johnson \& Johnson to treat mantle cell lymphoma and multiple myeloma (MM). According to the label, the recommended dose of the drug is $1.3 \mathrm{mg} / \mathrm{m}^{2}$ delivered via i.v. twice a week for two weeks followed by a ten-day rest period. The drug's side effects include peripheral neuropathy, pulmonary disorders and neutropenia.

In both cancer and lupus, Velcade is eliminating plasma cells. In the former case, these cells are malignant, but in lupus, none are malignant and only a fraction produce autoantibodies. Nonetheless, the Nature Medicine paper notes that bortezomib depleted both autoantibody-producing and normal plasma cells "without causing overt toxic effects in mice."

Moreover, the authors wrote, other immune effector cells, such as resting $B$ and $T$ cells, monocytes and dendritic cells "were not affected or were moderately affected particularly after prolonged treatment, indicating a certain level of selectivity for plasma cells."

Nevertheless, lupus researchers polled by SciBX emphasized the need for additional preclinical work before putting bortezomib into patients.

Prior to putting the drug into the clinic for lupus, Voll told SciBX that "it would be helpful to find a suitable combination therapy and to optimize the treatment schedule in animals before starting a clinical trial in antibody-mediated autoimmune diseases."

Voll is a researcher in the Department of Internal Medicine and 
Table 1. Lupus pipeline. A number of compounds for lupus are in late-stage development, with at least 11 products in Phase II or Phase III testing.

\begin{tabular}{|c|c|c|c|c|}
\hline Company & Product & Description & Indication & Status \\
\hline $\begin{array}{l}\text { Genelabs Technologies Inc. (NASDAQ: } \\
\text { GNLB)/Genovate Biotechnology Co. Ltd./Teva } \\
\text { Pharmaceutical Industries Ltd. (NASDAQ:TEVA)/ } \\
\text { Watson Pharmaceuticals Inc. (NYSE:WPI) }\end{array}$ & Prestara prasterone & Synthetic dehydroepiandrosterone hormone & $\begin{array}{l}\text { Systemic lupus } \\
\text { erythematosus } \\
\text { (SLE) }\end{array}$ & Phase III \\
\hline $\begin{array}{l}\text { Human Genome Sciences Inc. (NASDAQ:HGSI)/ } \\
\text { GlaxoSmithKline plc (LSE:GSK; NYSE:GSK) }\end{array}$ & $\begin{array}{l}\text { Belimumab } \\
\text { (LymphoStat-B) }\end{array}$ & $\begin{array}{l}\text { Human } \mathrm{mAb} \text { against B lymphocyte stimulator } \\
\text { protein }\end{array}$ & SLE & Phase III \\
\hline Galenica AG (SWX:GALN)/Roche (SWX:ROG) & $\begin{array}{l}\text { CellCept } \\
\text { mycophenolate } \\
\text { mofetil }\end{array}$ & $\begin{array}{l}\text { Reversible inhibitor of inosine monophosphate } \\
\text { dehydrogenase }\end{array}$ & Lupus nephritis & Phase III \\
\hline $\begin{array}{l}\text { Biogen Idec Inc. (NASDAQ:BIIB)/Genentech Inc. } \\
\text { (NYSE:DNA)/Roche }\end{array}$ & Rituxan rituximab & Chimeric $\mathrm{mAb}$ against $\mathrm{CD} 20$ antigen & Lupus nephritis & Phase III \\
\hline Biogen Idec/Genentech/Roche & Ocrelizumab & $\begin{array}{l}\text { Second-generation humanized } \mathrm{mAb} \text { against } \\
\text { CD20 }\end{array}$ & Lupus nephritis & Phase III \\
\hline La Jolla Pharmaceutical Co. (NASDAQ:LJPC) & Riquent abetimus & $\begin{array}{l}\text { Carrier plus four double-stranded } \\
\text { oligonucleotides that bind to anti-double- } \\
\text { stranded DNA antibodies on B cells }\end{array}$ & Lupus nephritis & Phase III \\
\hline $\begin{array}{l}\text { Immunomedics Inc. (NASDAQ:IMMU)/UCB Group } \\
\text { (Euronext:UCB) }\end{array}$ & Epratuzumab & Humanized $\mathrm{mAb}$ against $\mathrm{CD} 22$ & SLE & Phase III \\
\hline Bristol-Myers Squibb Co. (NYSE:BMY) & Orencia abatacept & $\begin{array}{l}\text { Cytotoxic T lymphocyte antigen } 4-\text { Ig fusion } \\
\text { protein }\end{array}$ & Lupus nephritis & Phase II/III \\
\hline $\begin{array}{l}\text { ZymoGenetics Inc. (NASDAQ:ZGEN)/Merck KGaA } \\
\text { (Xetra:MRK) }\end{array}$ & Atacicept & $\begin{array}{l}\text { Soluble fusion protein containing the } \\
\text { extracellular portion of transmembrane } \\
\text { activator and calcium modulator and } \\
\text { cyclophilin ligand interactor (TACI) linked } \\
\text { to Fc }\end{array}$ & $\begin{array}{l}\text { SLE; lupus } \\
\text { nephritis }\end{array}$ & Phase II/III \\
\hline Astion Pharma A/S & ASF-1096 & $\begin{array}{l}0.5 \% \text { cream formulation of R-enantiomer of } \\
\text { salbutamol (albuterol) }\end{array}$ & $\begin{array}{l}\text { Cutaneous lupus } \\
\text { erythematosus } \\
\text { (CLE) }\end{array}$ & Phase II \\
\hline ImmuPharma plc (LSE:IMM) & $\begin{array}{l}\text { Lupuzor } \\
\text { (IPP-201101) }\end{array}$ & $\begin{array}{l}\text { Peptide fragment analog including residues } \\
131-151 \text { of the spliceosomal U1-70K protein } \\
\text { with a phosphorylated serine at position } 140\end{array}$ & SLE & Phase II \\
\hline
\end{tabular}

the Institute of Clinical Immunology at the University of ErlangenNuremberg.

Noel Rose, professor and director of the Center for Autoimmune Disease Research at the Johns Hopkins Bloomberg School of Public Health, noted that bortezomib's specificity for normal-as opposed to malignant-plasma cells was unexpected. "The downside is that a proteasome inhibitor is predicted to have side effects in other rapidly proliferating cell types such as the gastrointestinal tract," he said. "These potential toxicities should be carefully addressed in lupus animal models before testing bortezomib in patients."

Tony Manning, VP of inflammation and autoimmune diseases at Biogen Idec Inc., also expressed concerns about treating lupus with bortezomib.

In addition to potential off-target tissue toxicity, Manning cautioned that bortezomib "could also deplete protective B cells, which might increase risk for opportunistic infection during long-term treatment. The authors also showed suppression of lymphocyte numbers in their studies. Thus, there's the concern that the dosing window could be too narrow to use the drug in humans without serious risk of adverse events."
Although plasma cells are being targeted in both lupus and multiple myeloma, Manning noted that "these are still two very different indications and patient populations."

Biogen Idec is exploring strategies that deplete plasma cells in lupus and other autoimmune diseases.

"We have two preclinical programs of note in this area," said Manning. "One of them is an antibody therapy that targets an undisclosed molecule that we believe is restricted to short-lived plasma cells. We are exploring the hypothesis that these cells are in large part responsible for the production of pathogenic autoantibodies that drive diseases such as lupus. The other is a small molecule inhibitor of the molecular chaperone Hsp90 [heat shock protein 90] that triggers the unfolded protein response in plasma cells, ultimately causing apoptosis.”

Biogen Idec also has multiple Phase III trials testing Rituxan and ocrelizumab, a second-generation anti-CD20 mAb, in general lupus and in lupus nephritis. A trial of Rituxan in lupus nephritis is ongoing, and initial data from the two ocrelizumab trials are expected at the end of 2009, Manning said.

Rituxan is marketed by Genentech Inc., Biogen Idec and Roche to treat non-Hodgkin's lymphoma (NHL) and rheumatoid arthritis 
(RA). The three companies are co-developing ocrelizumab.

Matthew Linnik, EVP and CSO of La Jolla Pharmaceutical Co., told SciBX, “The toxic nature of proteasome inhibitor therapy could mean that side effects like peripheral neuropathy and neutropenia limit its use to catastrophic forms of lupus that are associated with conditions like antiphospholipid syndrome, where autoantibodies to cell membrane phospholipids cause massive clotting in the circulation and organ systems."

Nevertheless, "the Nature Medicine paper illustrates an awareness among lupus researchers that plasma cells probably play a critical role in disease pathophysiology," said Linnik. "For very long periods of time, a plasma cell can occupy a survival niche in the bone marrow where it steadily pumps out antibodies or, in the case of lupus, autoantibodies, which help sustain disease. Moreover, these cells don't express CD20 on their surface and are therefore refractory to Rituxan and similar therapies that target B cells."

The question is how to exploit the plasma cell findings in the Nature Medicine paper while avoiding bortezomib's documented side effects in cancer patients.

"One obvious strategy would be to identify components unique to long-lived plasma cells and target those," said Linnik. "Unfortunately, these cells have historically been quite difficult to culture and work with. Nevertheless, a plasma cell-targeted therapy, if it existed, would probably have a reduced side-effect profile compared with a drug like bortezomib, which targets a pathway common to many cell types."

La Jolla's Riquent abetimus, a carrier molecule linked to four double-stranded oligonucleotides that binds anti-double-stranded
DNA autoantibodies on the surface of memory B cells, is in Phase III testing to treat lupus and lupus nephritis and to prevent renal flares.

"Autoantibodies against double-stranded DNA contribute to lupus nephritis and are also present in many nonrenal forms of lupus," said Linnik. "Abetimus is designed to specifically suppress activation of the $\mathrm{B}$ cell subpopulation that produces autoantibodies against double-stranded DNA without compromising the important immune function of the remaining B cells."
REFERENCES

1. Lipsky, P. Nat. Immunol. 2, 764-766 (2001)

2. Hansen, A. et al. Arthritis Res. Ther. 9, 215; published online July 11, 2007; doi:10.1186/ar2183

3. Manz, R. et al. Annu. Rev. Immunol. 23, 367-386 (2005)

4. Tarlinton, D. \& Hodgkin, P. J. Exp. Med. 199, 1451-1454 (2004)

5. Hoyer, B. et al. J. Exp. Med. 11, 1577-1584 (2004)

6. Meister, S. et al. Cancer Res. 67, 1783-1792 (2007)

7. Neubert, K. et al. Nat. Med.; published online June 8, 2008; doi:10.1038/nm1763 Contact: Reinhard Voll, University of Erlangen-Nuremberg, Erlangen, Germany e-mail: rvoll@molmed.uni-erlangen.de

\section{COMPANIES AND INSTITUTIONS MENTIONED} Biogen Idec Inc. (NASDAQ:BIIB), Cambridge, Mass. Genentech Inc. (NYSE:DNA), South San Francisco, Calif. German Arthritis Research Center, Berlin, Germany Johns Hopkins Bloomberg School of Public Health, Baltimore, Md. Johnson \& Johnson (NYSE:JNJ), New Brunswick, N.J. La Jolla Pharmaceutical Co. (NASDAQ:LJPC), San Diego, Calif. Millennium Pharmaceuticals Inc., Cambridge, Mass. Roche (SWX:ROG), Basel, Switzerland

Takeda Pharmaceutical Co. (Tokyo:4502), Osaka, Japan University of Erlangen-Nuremberg, Erlangen, Germany 